\title{
ELLJ
}

\section{The right to request flexible working arrangements under the Work-life Balance Directive - A \\ comparative perspective}

European Labour Law Journal

$|-2|$ (C) The Author(s) 2021

(c) (i)

Article reuse guidelines: sagepub.com/journals-permissions DOI: 10.1 |77/203|95252। I038270

journals.sagepub.com/home/ell

@SAGE

\section{Lisa Waddington (1)}

Maastricht University, Maastricht, Limburg, the Netherlands

Mark Bell (1)

Trinity College Dublin, University of Dublin, Dublin, Ireland

\begin{abstract}
The 2019 Work-life Balance Directive creates a new right for parents and carers to request flexible working arrangements for caring purposes. The significance of this innovation has been heightened by the pandemic because it includes the right to request remote working arrangements. This article undertakes a contextual and comparative analysis in order to understand better the strengths, limitations and opportunities created by the Directive. It compares the right to request flexible working arrangements to provisions found in existing Directives on parental leave and part-time work, as well as protections that may be derived from EU equality law. It looks also at examples of existing legislation in two jurisdictions, the Netherlands and Australia, in order to illustrate the options available to Member States when they implement this right within domestic law. The article concludes that the full potential of this right can only be understood when it is viewed as part of a wider range of legal provisions that assist in the reconciliation of work and family life.
\end{abstract}

\section{Keywords}

Flexible working, work-life balance, remote working, discrimination, reasonable accommodation

\section{Corresponding author:}

Lisa Waddington, Maastricht University, PO Box 616, 6200 Maastricht, the Netherlands.

E-mail: lisa.waddington@maastrichtuniversity.nl 


\section{Introduction}

The 2019 Work-life Balance Directive ${ }^{1}$ creates a new right for parents and carers to request flexible working arrangements for caring purposes, which must be transposed into domestic law by 2 August 2022. While the aspiration for flexibility in the organisation of work has been a prominent feature of contemporary EU employment policy, it is only through gradual and fragmented interventions that EU law has moved in the direction of giving workers enforceable rights that facilitate flexible working arrangements. ${ }^{2}$ The salience of this latest step along that path is, of course, accentuated by the subsequent onset of the pandemic. Flexible working arrangements, as defined by the Directive, include 'the use of remote working arrangements'. ${ }^{3}$ The Work-life Balance Directive means that the EU already has an instrument in its toolbox that provides a framework for how employers and (some) workers negotiate the future balance between working remotely and working at the workplace. Given this context, it is particularly important to expose the right to request flexible working arrangements to more detailed analysis.

This article adopts a comparative perspective in order to shed more light on the right to request flexible working arrangements. First, it sets out the right as established in the new Directive. Second, it compares this right with those measures that already exist in EU law that, directly or indirectly, may assist those who wish to have flexible working arrangements. Specifically, the article examines the Parental Leave Directive, ${ }^{4}$ which the new Directive will replace; the right to request to move to part-time or full-time work found in the Directive on Part-time Work $;^{5}$ and rights for carers that arise from EU equality law. The article also compares the right to request flexible working arrangements with another obligation to tailor work to the needs of the individual, namely, the duty to provide a reasonable accommodation in favour of disabled persons found in the Employment Equality Directive. ${ }^{6}$ In addition, the article considers the relationship that exists between the right and the EU Charter of Fundamental Rights, as well as the European Pillar of Social Rights. The third section of the article looks to national law in order to provide some examples of how the right contained in the Directive could be implemented and, in particular, how it could be magnified in domestic legislation. The purpose of this section is not to provide a comprehensive comparative analysis, but to highlight a few examples of regulatory options for domestic lawmakers. One example is from within the Union (the Netherlands) and one is from beyond (Australia).

1. Parliament and Council Directive 2019/1158/EU of 20 June 2019 on work-life balance for parents and carers and repealing Council Directive 2010/18/EU [2019] OJ L188/79.

2. See further, Eugenia Caracciolo di Torella and Annick Masselot, Reconciling Work and Family Life in EU Law and Policy (Palgrave MacMillan 2010); Nicole Busby, A Right to Care? Unpaid Care Work in European Employment Law (Oxford University Press 2011).

3. Art. 3(1)(f).

4. Clause 6(1), Council Directive 2010/18/EU of 8 March 2010 implementing the revised Framework Agreement on parental leave concluded by BUSINESSEUROPE, UEAPME, CEEP and ETUC and repealing Directive 96/34/EC [2010] OJ L68/13.

5. Council Directive 97/81/EC of 15 December 1997 concerning the Framework Agreement on part-time work concluded by UNICE, CEEP and the ETUC [1998] OJ L14/9, Clause 5(3).

6. Council Directive 2000/78/EC of 27 November 2000 establishing a general framework for equal treatment in employment and occupation [2000] OJ L303/16. 
Through this multi-dimensional comparison and contextualisation, the article aims to obtain a deeper understanding of the strengths, limitations and potential of the right, and to identify its relationship with existing rights established within EU (labour) law.

\section{The right to request flexible working arrangements under the Work-life Balance Directive}

In 2008, the Commission set out its agenda to achieve 'a better work-life balance'. ${ }^{7}$ This included reform of existing legislation on family-related leave. While changes were made to the Parental Leave Directive in 2010, agreement could not be reached on reforming the Maternity Leave Directive, where it had been proposed to extend the leave entitlement of women. ${ }^{8}$ In 2017 , the Commission relaunched its efforts, but this time with a different emphasis. ${ }^{9}$ A broader perspective on facilitating work-life balance for parents and carers was proposed. Notably, this moved beyond only granting periods of paid or unpaid leave from work and it placed more weight on finding ways to enable workers to combine working and caring through flexible working arrangements. The proposal for a Directive on Work-life Balance ${ }^{10}$ received a crucial political boost because it was linked to the relaunch of EU social policy through the European Pillar of Social Rights. ${ }^{11}$ The latter was proclaimed by the European Parliament, Council and Commission in November 2017 and it included work-life balance as one of its 20 principles. Set against this backdrop, there was a relatively swift process, with the main points of the Directive being politically agreed by the institutions in January 2019. ${ }^{12}$

The Impact Assessment accompanying the proposal noted that the unavailability of flexible working arrangements 'can lead to some workers, particularly women, to drop out of the labour market altogether when taking on caring responsibilities'. ${ }^{13}$ The Directive therefore provides workers with the right to request flexible working arrangements in order to enable them to carry out caring tasks. ${ }^{14}$ This is linked to a corresponding duty on employers to consider and respond to the request in a timely manner and, in case the request is refused, to provide reasons for the refusal or postponement of such arrangements. ${ }^{15}$

Flexible working arrangements are understood broadly to include 'the possibility for workers to adjust their working patterns including through the use of remote working arrangements, flexible working schedules, or reduced working hours'. ${ }^{16}$ Unlike other forms of leave addressed in the

7. Commission, 'A Better Work-life Balance: Stronger Support for Reconciling Professional, Private and Family Life' COM (2008) 635 final.

8. See further, Álvaro Oliviera, Miguel De La Corte-Rodríguez and Fabian Lütz, 'The New Directive on Work-life Balance: Towards a New Paradigm of Family Care and Equality?' (2020) 45 EL Rev 295, 297.

9. Commission, 'An Initiative to Support Work-life Balance for Working Parents and Carers' COM (2017) 252 final.

10. Commission, 'Proposal for a Directive of the European Parliament and of the Council on work-life balance for parents and carers and repealing Council Directive 2010/18/EU' COM (2017) 253 final.

11. [2017] OJ C428/10.

12. Oliveira et al (n 8) 301.

13. Commission Staff Working Document, 'Impact Assessment Accompanying the document Proposal for a Directive of the European Parliament and of the Council on work-life balance for parents and carers and repealing Council Directive 2010/18/EU'SWD (2017) 202 final, 7.

14. Art $9(1)$.

15. Art 9(2).

16. Art 3(f) and Recital 34. For a discussion of flexible working hours in particular, see Biljana Todorova and Makedonka Radulovikj, 'Work-Life Balance: Challenges of Gender Equality in the Labor Market of North Macedonia vs European Union' (2020) 4 EU and Comparative Law Issues and Challenges Series 751, 761-765. 
Directive, specifically paternity leave, parental leave and carers' leave, there is not an absolute right to receive flexible working arrangements for a care-related reason, but only a right to request such arrangements, and have the request seriously considered by the employer. Indeed, the Commission's executive summary of the impact assessment related to the proposal notes in this respect that 'the employer has no obligation to grant the requested change'. ${ }^{17}$ Workers who benefit from flexible work arrangements are entitled to return to their original working pattern at the end of the agreed period, and can also request to return to their original working pattern before the end of the agreed period. ${ }^{18}$ Workers who have requested or taken up flexible working arrangements are protected from discrimination on this ground. ${ }^{19}$

The right to request flexible working arrangements is conferred on parents of children of a specific age, which shall be at least eight years, ${ }^{20}$ and 'carers'. 'Carers' are defined in the Directive as a 'worker providing personal care or support to a relative, or to a person who lives in the same household as the worker, and who is in need of significant care or support for a serious medical reason'. ${ }^{21}$ A relative is defined as a worker's child, parent, spouse or civil partner. ${ }^{22}$ The exact definition of the term 'carers' is to be set by Member States, ${ }^{23}$ and Member States may allow flexible working arrangements to be requested by parents of children above the age of eight. ${ }^{24}$ Member States may limit the maximum duration of flexible working arrangements, although are not obliged to do so. ${ }^{25}$

A number of civil society organisations have criticised the definitions set out in Article 3 of the Directive. The European Women's Lobby has argued that 'limiting the definitions to the nuclearfamily model is not only obsolete as it does not reflect the reality of the diversity of families, it could result in the exclusion of many workers who are effectively carrying out parenting and caring responsibilities without being biologically related to the person(s) they are caring for' ${ }^{26}$ Academic commentators have also reflected on the definition of carers in the Directive. ${ }^{27}$ Weldon-Johns has noted that the definition of relatives for whom care may be provided 'reflects the traditional nuclear family by focusing on traditional bonds and presumed relationships of care, rather than

17. Commission Staff Working Document, 'Executive Summary of the Impact Assessment, Accompanying the document Proposal for a Directive of the European Parliament and of the Council on work-life balance for parents and carers and repealing Council Directive 2010/18/EU' SWD (2017) 203 final, 4.

18. Art 9(3).

19. Art 11.

20. The original Commission proposal indicated workers with children up to at least the age of twelve were to be entitled to request flexible working arrangements: Commission (n 10) Art 9(1).

21. Although the original Commission proposal contained a different definition of 'carer': “carer" means a worker providing personal care or support in the case of a serious illness or dependency of a relative': Commission, ibid, Art 3(b). The definition in the Commission proposal was more limited than the definition in the final Directive, in that it referred only to relatives and it did not refer to care recipients living in the same household as the worker.

22. Art 3(e).

23. Art 3(d).

24. Art 9(1).

25. Recital 35.

26. European Women's Lobby, 'Work-Life Balance Directive, The EWL Assessment of the recently adopted Directive on work-life balance for parents and carers', June 2019, 5. See also, COFACE Families Europe, 'Assessment of the EU Work-life balance Directive by COFACE Families Europe, New social rights, consolidation of existing social rights and some missed opportunities', 15 March 2019, 7.

27. On the 'markers' of being in a caring relationship, see Eugenia Caracciolo di Torella and Annick Masselot, Caring Responsibilities in European Law and Policy - Who Cares? (Routledge 2020) 7. 
focusing on responsibilities for care that may extend beyond defined familial roles' and 'it fails to acknowledge the diverse and complex relationships and responsibilities for care that may exist, such as care for other family members, neighbours or friends'. ${ }^{28}$ She also argues that the requirement that the care recipient be in need 'of significant care or support for a serious medical reason' may 'be interpreted narrowly and exclude a wide range of carers' ${ }^{29}$ Both elements noted by Weldon-Johns may therefore serve to restrict the right of workers to request flexible working arrangements for a care-related reason by focusing on characteristics required of the care recipient.

The Directive allows Member States the possibility to restrict the right to request flexible working arrangements for caring purposes to workers who have worked for the employer for a specific period, which cannot exceed six months. ${ }^{30}$ Chieregato notes that this may lead to the exclusion of those in non-standard forms of employment. ${ }^{31}$ While the right applies to both parents and people providing care to an adult, it is worth noting that parents and those providing care to an adult may have rather different needs. Hiessl argues 'while the intensity and duration of a child's need for care can be expected to follow a typical pattern (to which legally determined care-related entitlements can be adapted), the extent and development of care needs of an adult with a chronic condition are much more individual and less predictable'. ${ }^{32}$ She argues that flexible working arrangements, rather than a period of full-time leave devoted to caring, can be particularly relevant for workers who provide care to adults. ${ }^{33}$

As noted above, employers are under a duty to consider the request for flexible working arrangements, but are not obliged to grant the request. The Impact Assessment accompanying the Commission's legislative proposal stated that an absolute right to 'request flexible working' (presumably meaning a right to flexible working arrangements) was discarded 'as it would create serious restrictions for employers to determine how work is organised in a firm'. ${ }^{34}$ The Directive gives some indication of the factors employers should consider when deciding on a request, and makes clear that a balancing of interests is required, 'taking into account the needs of both the employer and worker'. ${ }^{35}$ Recital 36 of the Directive also indicates that the employer should be able to take into account, inter alia, 'the duration of the flexible working arrangements requested and the employers' resources and operational capacity to offer such arrangements'.

While the Directive requires that employers give serious consideration to a request, it does not indicate the procedure employers should follow when deciding how to respond. There is no requirement, for example, that the employer meet with the employee to discuss the request or communicate the decision to the employee in writing. Nevertheless, Oliveira et al have argued that while the Directive 'does not impose explicitly an obligation on the employer to adopt and

28. Michelle Weldon-Johns, 'EU work-family policies revisited: Finally challenging caring roles?' (2021) 12 European Labour Law Journal (forthcoming).

29. Ibid.

30. Art 9(4). It has been claimed that one in ten workers are not eligible for work-life balance entitlements, such as the right to take parental leave or the right to request flexible working arrangements for a care-related reason: Elisa Chieregato,

'A Work-Life Balance for All? Assessing the Inclusiveness of EU Directive 2019/1158' (2020) 36 International Journal of Comparative Labour Law and Industrial Relations 59, 75.

31. Ibid 76.

32. Christina Hiessl, 'Caring for Balance? Legal Approaches to Those Who Struggle to Juggle Work and Adult Care' (2020) 36 International Journal of Comparative Labour Law and Industrial Relations 107, 111.

33. Ibid 128 .

34. Commission Staff Working Document (n 13) 11 and 68.

35. Art 9(2). 
communicate to the worker in a written decision, ... doing so is certainly the best way of proving that the worker's request has been considered and that the worker has therefore been able effectively to exercise her/his rights' ${ }^{36}$ COFACE Families Europe and the European Women's Lobby argued that the Directive should have required employers to justify a refusal in writing. ${ }^{37}$ Member States have the possibility to set such a requirement when they transpose the Directive.

In contrast, Directive 2019/1152 on transparent and predictable working conditions ${ }^{38}$ which, alongside the Work-life Balance Directive, was one of the first Directives linked to the European Pillar of Social Rights to be adopted, does require workers to be informed in writing of the employer's decision when they make a request to change their employment status. Under the Directive, employers must respond within one month of receiving a request for employment with more predictable and secure working conditions, and the response must consist of a 'reasoned written reply'. ${ }^{39}$ It is unclear why such a response is not required for other requests to change the employment relationship under the Work-life Balance Directive.

\section{The right to request flexible working arrangements and pre-existing EU law}

This section of the article seeks to contextualise the right to request flexible working arrangements in the Work-life Balance Directive by comparing it to other provisions of existing EU law that, directly or indirectly, facilitate flexible working arrangements. The comparison helps to elucidate the extent to which the Work-life Directive enhances the law, but also how it may function in combination with other instruments, especially non-discrimination law.

The Parental Leave Directive and the Part-time Work Directive. The possibility to request flexible working arrangements is not completely new under EU law. A more restricted scope for making such a request existed under the Parental Leave Directive, ${ }^{40}$ which the Work-life Balance Directive replaces. Under the Parental Leave Directive only parents returning from parental leave could request flexible working arrangements regarding working patterns and working hours. Employers were not obliged to grant this request. The CJEU confirmed that the Directive could not be relied upon by a parent who wished to alter their working hours in a shift system, thereby working at fixed rather than variable times, but not to reduce those working hours. ${ }^{41}$ The new Directive also does not explicitly refer to working at fixed times as a form of flexible working arrangement, but this may nevertheless be a means of adjusting working patterns within the meaning of Article 3(1)(f). In contrast, remote working arrangements, flexible working schedules, and reduced working hours are all explicitly mentioned in the Article. However, as will be seen in section on the right to request flexible working arrangements under national law below, some national systems do allow parents to request fixed working patterns as well as more flexible or less working hours. A failure to allow parents and other carers to request fixed, as opposed to flexible, working schedules, may

36. Oliveira et al (n 8) 308.

37. COFACE Families Europe (n 26) 15 and European Women's Lobby (n 26) 8.

38. Parliament and Council Directive 2019/1152/EU of 20 June 2019 on transparent and predictable working conditions in the European Union [2019] OJ L186/105.

39. Art 12, Transition to another form of employment.

40. Directive 2010/18/EU, Clause 6(1).

41. Case C-366/18 José Manuel Ortiz Mesonero v UTE Luz Madrid Centro EU: C:2019:757, paras 45 et seqq. 
restrict the ability of some carers to combine work and care-related tasks, especially those tasks which occur at predictable times, such as when school or day care centres are closed.

Under the Work-life Balance Directive, the request for flexible working arrangements can be made at any moment subject to a (nationally determined) maximum age of the child, which cannot be less than eight years. In contrast, the Court has ruled under the Parental Leave Directive that a preliminary reference concerning a mother who requested a change to her working pattern after returning from maternity rather than parental leave was inadmissible, since it could not "be regarded as a request to change working hours or working pattern after "a return from parental" leave within the meaning of Clause 6(1) of the revised Framework Agreement [Parental Leave Directive]'. ${ }^{2}$

In addition, the Directive on Part-time Work requires employers to give consideration 'as far as possible' to workers' requests to move from full-time to part-time work and vice versa, ${ }^{43}$ and therefore also encompasses a limited right to request flexible working arrangements which is not confined to parents and carers. In terms of the obligation to justify a refusal to grant an employee's request under this Directive, Hiessl has noted that the CJEU has paid little attention to the duty employers are under to justify decisions to refuse to allow a worker to continue to work part-time, where this is needed for care reasons. This is reflected in Mascellani, ${ }^{44}$ in which a worker challenged her employer's decision to require her to resume full-time work, partly on the grounds that she needed to care for her elderly mother and this was incompatible with a full-time work schedule. The Court found that the Directive did not preclude national legislation which allowed an employer to convert an employment contract from part-time work to full-time work without the worker's consent. Hiessl notes that 'the fact that the CJEU did not even examine the employer's reason for requiring a return to full-time work indicates that it did not regard the Directive as requiring this reason to reach any particular standard of importance or urgency, let alone to be weighed against the interests of the employee'. ${ }^{45}$ Arguably, the extent of the obligation on an employer to justify a refusal to allow flexible working arrangements under the Work-life Balance Directive is also not established, and it is not clear if there will be, or can be, any judicial scrutiny of employer's justifications.

EU equality law. The Employment Equality Directive, which prohibits employment-related discrimination on the grounds, inter alia, of disability and age, as well as the Recast Directive on equal treatment of men and women in matters of employment and occupation, ${ }^{46}$ are also relevant in this context, although neither instrument explicitly refers to flexible working arrangements or explicitly prohibits discrimination on the ground of being a carer. ${ }^{47}$ In Coleman ${ }^{48}$ the CJEU held that the Employment Equality Directive protected a mother of a disabled child from direct discrimination

42. Case C-351/14 Estella Rodríguez Sánchez v Consum Sociedad Cooperativa Valenciana EU: C:2016:447, para 53. This was one of several reasons for declaring the request for a preliminary ruling to be inadmissible.

43. Council Directive 97/81/EC, Clause 5(3)(a) and (b).

44. Case C-221/13 Teresa Mascellani v Ministero della Giustizia EU: C:2014:2286.

45. Hiessl (n 32) 128-129.

46. Parliament and Council Directive 2006/54/EC of 5 July 2006 on the implementation of the principle of equal opportunities and equal treatment of men and women in matters of employment and occupation (recast) [2006] OJ L204/23.

47. See further, Caracciolo di Torella and Masselot (n 27) ch 4.

48. Case C-303/06 S. Coleman v Attridge Law and Steve Law EU: C:2008:415. 
and harassment, where that discrimination was based on the disability of her child. The prohibition of discrimination on the ground of disability therefore extended to a person who associated with an individual with a disability. This could, for example, cover the situation where parents of children without disabilities received better treatment, including benefitting from flexible working arrangements, than parents of children with disabilities. Indeed, one form of adverse treatment alleged by Ms. Coleman was the refusal 'to allow her the same flexibility as regards working hours... as those of her colleagues who [were] parents of non-disabled children' ${ }^{49}$ The prohibition of direct discrimination by association could potentially also be relevant in other situations, such as where a male carer receives worse treatment than a female carer, and this adverse treatment can be linked to his association with a disabled or elderly relative who he provides care for.

Discrimination by association can also be relevant in the context of indirect discrimination. This could arise, for example, where an employer requires all workers to carry out shift work, and the shifts are automatically rotated, so that all workers work all of the shifts over a fixed period. This could particularly disadvantage carers, such as single parents or others who are sole carers, who may find it difficult to work at certain hours, such as early in the morning when children need to be brought to school, or at night, when other (professional) carers may not be available.

In Coleman the Court did not address, in any way, the situation with regard to indirect discrimination by association. However, in the case of $\mathrm{CHEZ}^{50}$ the Court did indicate that indirect discrimination by association was also prohibited by EU equality law. This might mean that a carer who wishes to work flexibly in order to combine care and work, and who is hampered in this by standard employment policies or working arrangements, could argue that they are subject to indirect discrimination by reason of the disability or age of the person they care for. However, in recognition of the fact that most carers are women, ${ }^{51}$ female carers might not have to take this round-about route, and could argue that policies or arrangements which hamper them in fulfilling their caring roles amount to indirect discrimination against them 'directly', and not 'by association'.

An example of such a case is London Underground Ltd. $v$ Edwards. ${ }^{52} \mathrm{Ms}$. Edwards was a train driver and a single mother, and challenged a new shift system that made it far more difficult for her to combine her work and childcare responsibilities than previously. She alleged that the new system was harder for single parents to comply with than was the case for other workers, and that the system amounted to indirect sex discrimination, given that women were far more likely than men to be single parents. Ultimately, the case turned on whether the new shift system created a requirement that 'is such that the proportion of women who can comply with it is considerably smaller than the proportion of men who can comply with it'. ${ }^{53}$ Simon Brown LJ found that ' ... it would seem to me wrong to ignore entirely the striking fact here that not a single man was disadvantaged by this requirement despite the vast preponderance of men within the group. Looked at in the round, this requirement clearly bore disproportionately as between men and women, even though only one woman was affected by it'. ${ }^{54}$ As a result, the Court of Appeal found that the

49. Para 26.

50. Case C-83/14 CHEZ Razpredelenie Bulgaria AD v Komisia za zashtita ot diskriminatsia EU: C:2015:480.

51. Caracciolo di Torella and Masselot (n 27) 13.

52. London Underground Ltd $v$ Edwards (No. 2) [1999] ICR 494 (CA).

53. This was a requirement for the establishment of indirect discrimination against women under the Sex Discrimination Act s. 1(1)(b).

54. London Underground Ltd (n 52) para 49. 
employer was obliged to allow Ms. Edwards to work shifts that would enable her to combine her work and childcare responsibilities, and had indirectly discriminated against her by not doing this. ${ }^{55}$

EU equality law, through both the Recast Directive and the Employment Equality Directive, and through the application of the rules on direct and indirect discrimination (by association), therefore offer carers various possibilities to challenge work schedules and other practices which make it more difficult for them to combine care and work, and, in some circumstances, to claim the right to work in a way which allows them to make this combination.

\section{The right to request flexible working arrangements and the duty to provide a reasonable accommodation under EU equality law}

The duty to provide reasonable accommodation under EU law. The right to request flexible working arrangements bears certain similarities with the duty to provide a reasonable accommodation in favour of a person with a disability found in the Employment Equality Directive, and across national and international non-discrimination and disability rights legislation. Under EU law, the obligation to provide a reasonable accommodation to disabled individuals was established by the Employment Equality Directive of 2000. Article 5 of that Directive provides:

In order to guarantee compliance with the principle of equal treatment in relation to persons with disabilities, reasonable accommodation shall be provided. This means that employers shall take appropriate measures, where needed in a particular case, to enable a person with a disability to have access to, participate in, or advance in employment, or to undergo training, unless such measures would impose a disproportionate burden on the employer.

The obligation to make a reasonable accommodation on the grounds of disability is based on the recognition that, on occasions, the interaction between an individual's impairment and the physical or social environment can result in the inability to perform a particular function, job or activity in the conventional manner. The characteristic of impairment is relevant in that it can lead to an individual being faced with a barrier that prevents him or her from benefiting from an employment or other opportunity that is open to others who do not share that characteristic. This barrier can be removed through an individualised and tailored reasonable accommodation. Recital 20 of the Directive provides some guidance on what amounts to an accommodation. It states: '[a]ppropriate measures should be provided, i.e. effective and practical measures to adapt the workplace to the disability, for example, adapting premises and equipment, patterns of working time, the distribution of tasks or the provision of training and integration resources' ${ }^{56}$

The duty to provide an accommodation to a disabled individual is not absolute, and can be removed when providing the accommodation would result in a disproportionate burden for the employer. Recital 21 of the Directive refers to some factors which should be taken into account to

55. Information on this case draws on text in Lisa Waddington, 'Reasonable Accommodation - Time to Extend the Duty to Accommodate Beyond Disability?' (2011) 38 Nederlands Tijdschrift voor de Mensenrechten, NJCM-Bulletin, 186, 192-193. See also, Hardy and Hansons plc v Lax [2005] IRLR 726 (CA) holding that a refusal to consider a request to transfer to part-time work or to job-share after maternity leave constituted indirect sex discrimination.

56. Text in this paragraph draws on Lisa Waddington, 'Reasonable Accommodation' in Dagmar Schiek, Lisa Waddingtonand Mark Bell (eds), Cases, Materials and Text on National, Supranational and International Non-Discrimination Law (Hart Publishing 2007) 627. 
determine whether a measure amounts to a disproportionate burden. These are 'the financial and other costs entailed, the scale and financial resources of the organisation or undertaking and the possibility of obtaining public funding or any other assistance'. A further limitation is that the duty, under EU law, is confined to the spheres of employment and vocational training.

The duty to provide a reasonable accommodation is also established in the UN Convention of the Rights of Persons with Disabilities (CRPD or Convention) to which the EU is a party. Article 2 CRPD defines 'discrimination on the basis of disability' and includes within that definition the denial of reasonable accommodation. Article 5(3) of the CRPD links the equality and nondiscrimination norms with the duty to accommodate, and should be read together with the definition of reasonable accommodation in Article 2, which provides:

'Reasonable accommodation' means necessary and appropriate modification and adjustments not imposing a disproportionate or undue burden, where needed in a particular case, to ensure to persons with disabilities the enjoyment or exercise on an equal basis with others of all human rights and fundamental freedoms.

\section{Comparing the right to request flexible working arrangements and the right to reasonable} accommodation. The right to request flexible working arrangements equates to a right to require the employer to consider accommodating the needs of an employee. An element of accommodation or adjustment is therefore at issue. However, one should not stretch the comparison between the right to request flexible working arrangements and the reasonable accommodation duty too far. The duty to provide a reasonable accommodation is more far reaching than the duty to consider a request for flexible working arrangements. In this respect, a distinction can be drawn between 'procedural' and 'substantive' accommodation duties. ${ }^{57}$ Procedural duties can be described as those where the law provides an entitlement for the worker to make a certain type of request and, in response, this triggers a statutory obligation for the employer to consider that request and to issue a decision. The employer has a duty to participate in this process, but the law does not circumscribe the managerial prerogative of the employer with regard to whether the request is granted or denied. ${ }^{58}$ The duty under the Work-Life Balance Directive is procedural insofar as it is primarily focused upon the steps that the employer needs to take in response to a request for flexible working arrangements, rather than obliging the employer to grant such requests.

In contrast, the duty to provide reasonable accommodation can be characterised as a 'substantive' duty because it seeks to achieve a specific outcome: removing or mitigating barriers that the worker experiences to her participation or advancement in the job. ${ }^{59}$ This is a more onerous obligation for an employer, which is reflected in the greater constraints that it imposes on managerial decision-making; it is more difficult to justify a refusal to a provide an accommodation than it is to justify a refusal to provide flexible working arrangement. A 'good reason', which is based on legitimate business considerations, may not be sufficient to remove the accommodation duty, but it may be a permitted reason for declining a request to work flexibly. Instead, in the context of

57. Mark Bell, 'Adapting work to the worker: The evolving EU legal framework on accommodating worker diversity' (2018) 18 International Journal of Discrimination and the Law 124.

58. Ibid 138 .

59. Ibid 137. 
reasonable accommodation, the employer must show a much greater degree of hardship or difficultly, amounting to a 'disproportionate burden', before legitimately refusing a request. Nevertheless, the exact limits of both duties can be unclear.

In the context of requesting flexible working arrangements, Hiessl has noted 'a delicate question is how to deal with the inherent vagueness of an employer's duty to accommodate the employee's individual requirements as much as possible, and the resulting difficulty in assessing whether the duty has been lived up to ${ }^{90}$ and 'it is inherently difficult to set a justiciable standard for what the employer should be obliged to agree to'. ${ }^{61}$ This reflects the aforementioned lack of clarity. Nevertheless, Hiessl argues that the 'main innovation' the Work-life Balance Directive brings for carers is "the stipulation of a right to request "flexible working arrangements" in somewhat more binding terms'. ${ }^{62}$ However, she also notes the different approaches in the Directive to regulating the refusal to grant permission for flexible working conditions compared to parental leave. The employer can only postpone the taking of parental leave 'for a reasonable period of time on the grounds that taking of parental leave at the time requested would seriously disrupt the good functioning of the employer' ${ }^{63}$ Hiessl argues that 'under a systematic interpretation of the Directive, the very fact that such strong language is used in relation to parental leave implies that no such "serious disruption" of the employer's good functioning is required for rejecting requests for flexible arrangements'. ${ }^{64}$ It is unclear how demanding the Directive is in requiring that a refusal to grant flexible working arrangements be justified, and whether any justification could be regarded as insufficient under the Directive.

While the duty for the employer to consider flexible working arrangements seems only to be triggered once a worker makes an explicit request, the Employment Equality Directive is not explicit in requiring a worker to request a reasonable accommodation before the duty is triggered. In many cases, one can expect that such a request from a worker will be the starting point for the investigation, and putting into place, of an accommodation; however, one could envisage that the duty would also be triggered when an employer becomes aware that a worker is facing disabilityrelated barriers, either through their own observations or when informed by a relevant third party, such as an occupational health doctor.

A further difference between the two duties concerns the point at which individuals are entitled to benefit from the accommodation or acquire the right to request flexible working. EU law does not allow Member States to restrict the right to benefit from a reasonable accommodation to disabled individuals with a minimum period of employment. In fact, the duty is even owed to job applicants during the recruitment phase, and disabled workers are entitled to a reasonable accommodation from the very start of their employment. In contrast, EU law allows for the right to request flexible working arrangements to be conditional on a minimum period of work of not more than six months with the employer of whom the request is made.

Lastly, the range of actions which an employer must potentially take in the context of reasonable accommodation are potentially quite far-reaching, while the actions required to establish flexible working arrangements are more restricted. Article 3(1)(f) of the Work-life Balance

\footnotetext{
60. Hiessl (n 32) 119 .

61. Ibid 120 .

62. Ibid 129.

63. Art 5.

64. Hiessl (n 32) 130.
} 
Directive defines flexible working arrangements as 'the possibility for workers to adjust their working patterns', while Recital 34 of the Directive also mentions 'working schedules'. On the face of it, 'patterns' or 'schedules' do not seem to extend to other types of accommodation, such as allowing a worker to transfer to another position which is less physically or mentally demanding, or allowing a worker to transfer to another location/work site, even though that may enable the worker (better) to carry out caring tasks. Of course, the Directive does not in any way prohibit a worker from making such a request, nor does it restrict an employer who is willing to consider a wider range of adjustments. ${ }^{65}$ They would not, however, seem likely to be underpinned by the legal rights found in the Directive.

The two duties are, however, similar in that they can be regarded as 'assimilationist' and cannot bring about a radical restructuring of society, either by creating an equitable distribution of care tasks between men and women or creating a society in which people with impairments do not face disabling barriers. Whilst the right to request flexible working arrangements is framed in a genderneutral way, it does not address the societal and economic pressures and realities which lead to women being far more likely than men to take on caring roles. As such, it is based on the formal model of equality. Russell and Masselot have therefore argued:

The default workplace norm in many institutions of progression being dependent on long and unpredictable hours is clearly detrimental to those with caring responsibilities. Leaving that structure in place but implementing a statutory right for employees to request flexible hours may address the issue, but risks highlighting a perceived negative trait associated with those with caring responsibilities: a lack of flexibility.... If legislators and policy-makers were to take as a point of departure the centrality of care to our productive lives, workplaces might be shaped in ways that are radically different to the current norm. ${ }^{66}$

The duty to make a reasonable accommodation can also be regarded as failing to address the underlying norms which exclude and discriminate against disabled people. Specifically, where an accommodation is made to address the specific barriers faced by a particular disabled individual, the barrier itself and its causes and negative impact on disabled people in general can remain unaddressed. The Canadian authors Day and Brodsky have argued:

The difficulty with that paradigm is that it does not challenge the imbalances of power, or the discourses of dominance, such as racism, able-bodyism and sexism, which result in a society being designed well for some and not for others. It allows those who consider themselves 'normal' to continue to construct institutions and relations in their image, as long as others when they challenge this construction are 'accommodated'. ${ }^{67}$

In conclusion, while the right to request flexible working arrangements can be regarded as a right to request a particular form of accommodation, the right is less far-reaching than the right to

65. There are already examples of good practices where employers choose to allow workers to request a wide variety of workplace adjustments: International Labour Organisation, 'Promoting Diversity and Inclusion Through Workplace Adjustments: a Practical Guide' (ILO 2016) 23.

66. Roseanne Russell and Annick Masselot, 'Why Do We Care? The Shifting Concept of Care in New Zealand and in the United Kingdom' (2020) 36 International Journal of Comparative Labour Law and Industrial Relations 81, 103.

67. Shelagh Day and Gwen Brodsky, 'The Duty to Accommodate: Who Will Benefit?' (1996) 75 Canadian Bar Review $433,462$. 
a reasonable accommodation found under the Employment Equality Directive, which amounts to a right to receive an accommodation unless this would result in a 'disproportionate burden' for the employer. Nevertheless, a comparison of the two rights reveals a number of similarities, including the balancing of interests that is required in response to a request and the fact that both rights fail to bring about far reaching structural changes.

Flexible working arrangements and the EU charter of fundamental rights. Finally, and for completeness, it is worth briefly considering the relationship between the right to request flexible working arrangements and the EU Charter of Fundamental Rights (CFR). The Preamble of the Work-life Balance Directive refers to two provisions of the CFR: Article 23 CFR on equality between women and men and Article 33 on family and professional life. ${ }^{68}$ With regard to Article 23 CFR, this implies that women and men must have equal access to flexible working arrangements insofar as these are provided by an employer. Although not expressly mentioned in the Work-life Balance Directive, this is also an obligation flowing from Article 21(1) CFR, which prohibits discrimination on a range of grounds, including sex.

Article 33 CFR is composed of two paragraphs. The first is a broad statement that 'the family shall enjoy legal, economic and social protection'. The second paragraph is specifically mentioned in Recital 3 of the Preamble of the Work-life Balance Directive. It states: 'To reconcile family and professional life, everyone shall have the right to protection from dismissal for a reason connected with maternity and the right to paid maternity leave and to parental leave following the birth or adoption of a child'. This provision associates work-life balance with family-related leave for parents, which reflected the state of the legislation at the time when the Charter was adopted. ${ }^{69}$ As mentioned earlier, the novelty of the Work-life Balance Directive lies in its inclusion of carers (not only parents) and its emphasis on enabling the combination of working and caring, rather than only facilitating timeoff for caring. These elements are not explicitly reflected in Article 33, so it remains unclear whether it entails any obligations to protect carers and/or to facilitate flexible working arrangements.

Arguably, Article 33(2) is not an exhaustive statement of the measures required by the broader aim of protecting families, as set out in Article 33(1). The explanatory notes attached to the Charter state that Article 33 CFR is based on several provisions of the Revised European Social Charter (RESC).$^{70}$ Of these, it is notable that Article 27 RESC provides that states should take appropriate measures 'to enable workers with family responsibilities to enter and remain in employment' and 'to take account of their needs in terms of conditions of employment' ${ }^{71}$ Interpreting this provision, the European Committee of Social Rights has held that 'measures need to be taken to implement this provision, especially measures concerning the length and organisation of working time. Furthermore, workers with family responsibilities should be allowed to work part-time'. ${ }^{72}$ This connection between Article 27 RESC and Article 33 CFR would favour an interpretation of the

68. Recitals 2 and 3.

69. See further, Silvia Borelli, 'Article 33 CFREU Family and Professional Life' in Edoardo Ales, Mark Bell, Olaf Deinert and Sophie Robin-Olivier (eds), International and European Labour Law: Article-by-Article Commentary (Nomos 2018) 225; Caracciolo di Torella and Masselot (n 2) ch 1.

70. Arts 8 (protection of maternity), 16 (social, legal and economic protection of the family) and 27 (equal opportunities for workers with family responsibilities): Explanations relating to the Charter of Fundamental Rights [2007] OJ C303/17.

71. Art 27(1)(a)-(b) RESC.

72. Conclusions 2005, Lithuania, <http://hudoc.esc.coe.int/eng?i=2005/def/LTU/27/1/EN> (accessed 24 June 2021). See further, Karin Lukas, The Revised European Social Charter - an Article-by Article Commentary (Edward Elgar 2021). 
latter that extends to adjustments to working arrangements that facilitate the reconciliation of family and professional life.

Such an interpretation of Article 33 is further supported by reference to the European Pillar of Social Rights. Principle 9 on 'work-life balance' states that 'parents and people with caring responsibilities have the right to suitable leave, flexible working arrangements and access to care services' (emphasis added). The Pillar is not a legally-binding instrument and the Court has yet to consider its relationship to the Charter. It is, though, persuasive evidence that the EU's institutions regard the right to flexible working arrangements as forming part of the social rights recognised by the Union. Moreover, Principle 9 of the European Pillar of Social Rights is mentioned in Recital 9 of the Preamble of the Work-life Balance Directive.

The significance of this discussion lies primarily in the approach of the CJEU to the interpretation of the right to request flexible working arrangements. The Court has already recognised that certain provisions of the Parental Leave Directive should be interpreted in the light of Article 33(2) CFR. In Caisse pour l'avenir des enfants, it held that:

the individual right of each working parent to parental leave on the grounds of the birth or adoption of a child ... must be interpreted as articulating a particularly important EU social right which, moreover, is laid down in Article 33(2) of the Charter of Fundamental Rights. It follows that that right cannot be interpreted restrictively. ${ }^{73}$

This does not, in itself, alter the parameters of the right, but it encourages the Court to be expansive in its interpretation and to read narrowly any restrictions on its exercise. In that case, this led the Court to reject an interpretation of the Parental Leave Directive that confined its rights to those who were in employment at the time when their child was born or adopted. ${ }^{74}$ So it will be relevant to how the Court interprets the Work-life Balance Directive whether it deems the right to request flexible working arrangements to be an articulation of rights found in the Charter. That said, it must be acknowledged that the right to request flexible working arrangements entails a balancing of worker and employer interests. In several cases, the Court has recognised the applicability of Article 16 CFR on 'freedom to conduct a business' when considering legislation that may impinge upon certain interests of employers. ${ }^{75}$ For example, in Achbita, ${ }^{76}$ which concerned an employer's prohibition on the wearing by workers of religious, political or philosophical symbols, the Court held that 'an employer's wish to project an image of neutrality towards customers relates to the freedom to conduct a business that is recognised in Article 16 of the Charter' ${ }^{77}$ Consequently, invoking the Charter does not necessarily mean that the Court will interpret the right to request flexible working arrangements in a one-sided manner that systematically favours the interests of workers over those of employers.

73. Case C-129/20 Caisse pour l'avenir des enfants (Emploi à la naissance) EU: C:2021:140, para 44.

74. Ibid para 46.

75. See, inter alia, Case C-426/11 Alemo-Herron and Others EU: C:2013:521, para 33; Case C-210/15 AGET Iraklis EU: C:2016:972, para 66.

76. Case C-157/15 Achbita, Centrum voor gelijkheid van kansen en voor racismebestrijding v G4 S Secure Solutions NV EU: C:2017:203.

77. Para 38. 


\section{The right to request flexible working arrangements under national law}

The right to request flexible working arrangements is already found in a number of legislative provisions at national level, both within and outside the European Union. This section of the article examines two such provisions. This is done in light of the fact that, firstly, Member States which already recognise the right to request flexible working arrangements in a way which meets the minimum requirements set out in the Work-life Balance Directive will not be required to make any changes in this respect to transpose the Directive. However, those Member States cannot use the Directive to justify a general reduction in already existing rights. ${ }^{78}$ Secondly, this analysis is useful in that it can provide examples of how to establish a right to request flexible working arrangements which goes beyond the minimum requirements. The Directive explicitly recognises that this is possible, without requiring Member States to do so. ${ }^{79}$ The legislative and policy framework in the Netherlands and Australia are illustrative in this respect. ${ }^{80}$

The Netherlands. The Dutch Flexible Work Act, in force as of 2016, grants workers a right to request changes to their working arrangements, and imposes a number of procedural requirements on employers, although without obliging them to grant the request. All workers ${ }^{81}$ who have been employed for at least 26 weeks by their employer ${ }^{82}$ are entitled to request a change to their working arrangements, meaning that the right is not limited to workers who wish to make changes for a care-related reasons, as under the Work-life Balance Directive. Indeed, the Flexible Work Act makes no reference to the reasons why workers may wish to alter their working arrangements, and this is not a factor which is relevant to the decision whether to grant the request or not. ${ }^{83}$ The employee is also not obliged to inform the employer of the reasons for the request. Workers are entitled to request to reduce or increase the number of hours worked, to request a change to their place of work, including requesting to work from home, or to request a change to their working times. ${ }^{84}$ The changes which can be requested are therefore somewhat broader than those foreseen under the Directive. The request must be made in writing at least two months before the requested change is to take effect, and provide precise information on the requested change, e.g. start date and duration. ${ }^{85}$

As under the Work-life Balance Directive, employers are not obliged to grant the request, but are subject to a number of procedural requirements and the request can only be refused if certain requirements are met. The employer must discuss the request with the employee and is obliged to grant a request to change the number of hours worked or the time that is worked unless compelling business or service-related reasons justify a refusal. A somewhat less stringent test applies to

78. Art 16(2), Directive 2019/1158.

79. Art 16(1).

80. An alternative example can be found in Britain. Any qualifying employee is entitled to make a request for changes to their working hours, times and location. A request must be dealt with reasonably by the employer and it can only be refused on the basis of specified grounds set out in the legislation: Employment Rights Act 1996, ss 80F-80I.

81. At present, the right is not available to employees who work for an employer with less than ten employees (Art 2(16)). The Dutch law will be amended in this respect to comply with the Work-life Balance Directive.

82. Art 2(1).

83. J.G.F.M. Hoffman, Arbeidsovereenkomst, Art 2 Wfw., aant 2, Sancties op niet-nalevering van Art 2 Wfw, Kluwer (version 20.2.2019) and Hof Arnhem, 10 December 2002, JAR 2003/70.

84. Art 2(3). Ktr. Zutphen, 26 November 2002, JAR 2003/8.

85. Art 2(3). 
refusing requests to change the place of work. ${ }^{86}$ The Act lists a number of situations which will be considered to amount to such reasons, without, however, excluding other reasons. In this respect the Act addresses requests to reduce or increase working time and requests to change the time at which work is done. For example, in the case of a reduction in working time, a compelling business or service-related reason justifying a refusal will exist if the requested change would lead to serious problems regarding operational management in terms of re-allocating the hours the worker no longer works; safety; or shift patterns/work timetables. ${ }^{87}$ In the case of an adjustment to an employee's work schedule, a compelling business or service-related reason will exist if granting the request would lead to serious problems regarding safety; work patterns/timetables; or finances and organisation. ${ }^{88}$

If an employer fails to comply with the procedural requirements set out in the Act, or refuses to grant the request for a reason which the employee believes is not permissible under the Act, the employee can challenge the (lack of) action or decision before a court. There are numerous cases in which courts have found that an employer's justification for the refusal did not meet the stringent requirements of the Act. ${ }^{89}$ In such cases, a court can order that the employer grant the requested change and pay damages for the delayed start to the new working arrangements. ${ }^{90}$ In one case, an appeal court established an arrangement which met both the care-related needs of the employee and the business interests of the employer in the view of the court. The case involved a woman who worked as a receptionist in a dental practice for three days a week, and who had requested to be allowed to start work late each day, so that she could look after her children and bring them to school. The employer had refused this request. The court found that the worker could start work late on two of the three days, but had to be present at the start of the third day and make other arrangements for the care of her children on that day. ${ }^{91}$ The decision of the employer to refuse a request must therefore be objectively justifiable and can be subject to judicial scrutiny to establish that it meets the requirements set out in the Act. ${ }^{92}$

If a request is declined, the employee must receive written notification and an explanation of the decision. ${ }^{93}$ If an employer has not communicated a decision to the employee a month before the requested change would be due to come into effect, the working hours, place of work or work time will be adjusted in line with the request. ${ }^{94}$ An employer may revise a decision made in response to an employee's request if the situation changes, and substantial business interests or service-related interests which justify a change subsequently arise. In such a situation, the employer must consult with the employee and inform him or her about the reasons for the revised decision. ${ }^{95}$ If a request is

86. J.G.F.M. Hoffman, Arbeidsovereenkomst, Art 2 Wfw., aant 13, De beslissing van de werkgever, Kluwer (version 20.2.2019).

87. Art. 2(10).

88. Art. 2(11).

89. J.G.F.M. Hoffman, Arbeidsovereenkomst, Art 2 Wfw., aant 14, 14 Zwaarwegende bedrijfsbelangen, Kluwer (version 20.2.2019).

90. J.G.F.M. Hoffman, (n 83).

91. Hof's-Hertogenbosch, 5 October 2010, LJN BN9903 and J.G.F.M. Hoffman, Arbeidsovereenkomst, Art 2 Wfw., aant 16, Werkgeversbelang bij andere spreiding van de arbeidsuren, Kluwer (version 20.2.2019).

92. J.G.F.M. Hoffman, Arbeidsovereenkomst, Art 2 Wfw., aant 3, Het recht op aanpassing van de arbeidsduur, arbeidsplaats, werktijd, Kluwer (version 20.2.2019).

93. Art 2(8).

94. Art 2(12).

95. Art 2(13) and (14). 
refused, an employee can submit a new request a year after a decision was made on the previous request. This waiting period is removed in the case of unforeseen circumstances, ${ }^{96}$ which arguably may include an unexpected need to provide care for another. ${ }^{97}$ Lastly, collective agreements can deviate from the Act in a way which disadvantages workers with regard to requests concerning an increase in working hours, alternative work place or work times, ${ }^{98}$ and also allow an employer to rely on more lenient reasons for refusing such a request. ${ }^{99}$ On the other hand, such agreements can confer greater rights on workers by, for example, reducing the 26-week employment qualifying period. $^{100}$

The Dutch Flexible Work Act establishes quite a far-reaching right to request flexible working arrangements, which is not restricted to employees who have care-related tasks. A change to working arrangements, which can include working longer hours or working fixed hours (i.e. working arrangements which are 'less flexible') can be requested by all employees who have been employed for at least 26 weeks by the employer of whom they make the request. Employers are in turn subject to certain procedural requirements, including the obligation to discuss the request with the employee and to provide an explanation in writing for any refusal, and are subject to limitations regarding the acceptable reasons for declining to grant a request. A failure to respond to a request in a timely manner leads to the requested changes coming into effect. Overall, therefore, the right to request changes to working arrangements under Dutch law is broader in scope, and subject to more procedural requirements, than under the Work-life Balance Directive.

Australia. Australian law and mandatory industrial awards provide a further example of an alternative way of regulating requests for flexible working arrangements at the domestic level which go beyond the minimum standards set in the Work-life Balance Directive. Recent academic research on domestic provisions regarding the right to request flexible working conditions also provides further insight into the situation in Australia, as noted below.

The Australian Fair Work Act ${ }^{101}$ establishes, inter alia, a right to request a change to working arrangements in order to facilitate care-related tasks as well as in certain other circumstances. ${ }^{102}$ As in the case of the Work-life Balance Directive, this is a procedural right, and there is no duty on the employer to grant such a request. However, as in the Netherlands, the procedural obligations which an employer must comply with following receipt of such a request are more stringent than those found in the Directive.

The Fair Work Act provides that a request to change working arrangements can be made by employees who are parents or care for school-age children as well as carers as defined in the

96. Art 2(3).

97. In Kamerstukken I 1999/00, 26358 , nr. 52 C (document published by the Government for the Parliament) the death of a partner, leading to a worker wishing to reduce his/her working hours in order to care for children, was given as an example of unforeseen circumstances. J.G.F.M. Hoffman, Arbeidsovereenkomst, Art 2 Wfw., aant 10, Eenmal per jaar een verzoek, Kluwer (version 20.2.2019).

98. Art. 2(15).

99. J.G.F.M. Hoffman, Arbeidsovereenkomst, Art 2 Wfw., aant 1, Het rechtskarakter, Kluwer (version 20.2.2019). CRvB 25 July 2013, ECLI: NL: CRVB:2013:1177TAR.

100. Ibid.

101. Lisa Waddington is grateful to Professor Anna Chapman of Melbourne University Law School for providing information regarding the right to request a change to working arrangements in Australia.

102. Pt 2-2 Fair Work Act 2009 (Cth). 
Carer Recognition Act 2010. ${ }^{103}$ A worker who is providing care or support to a member of their immediate family or a member of their household because that person is experiencing violence from a family member can also make such a request. In addition, a request can be made by a worker with a disability or a worker aged over $55 .{ }^{104}$ Workers must have 12 months of 'continuous service' or be a 'long term casual employee' in order to be entitled to make the request. ${ }^{105}$ The Fair Work Act therefore imposes stricter requirements concerning an employee's employment history than does the Work-life Balance Directive, but allows a broader group of workers to make the request. Nevertheless, mothers returning from maternity leave are most likely to make requests, and typically request a move from full-time to part-time work. ${ }^{106}$

The relevant Part of the Fair Work Act uses similar language to the Directive and refers to 'flexible working arrangements'. ${ }^{107}$ The Act indicates that what workers can request is 'a change in working arrangements ${ }^{108}$ and gives the following examples of such changes: changes in hours of work, changes in patterns of work and changes in location of work.

The worker must make the request for a change in their working arrangements in writing. ${ }^{109}$ The employer must then respond in writing within 21 days, informing the worker of whether the request has been granted or not. ${ }^{110}$ If the employer declines the request, the written response must 'include details of the reasons for refusal' and the refusal must be based on 'reasonable business grounds'. ${ }^{111}$ Following a 2013 amendment, the Fair Work Act sets out an inclusive list of what constitute such grounds: 'too costly for the employer', 'impractical', 'likely to result in a significant loss of efficiency or productivity', 'likely to have a significant negative impact on customer service', or 'no capacity' to make the change (s 65 (5A)). A refusal to grant a request to change an employee's working arrangements which is not based on 'reasonable business grounds' cannot be challenged before the courts. However, Chapman has argued that such a decision may be subject to a legal challenge through a number of other routes, including as a prohibited form of discrimination. ${ }^{112}$ Moreover, a failure to comply with the relevant procedural requirements, including providing a reasoned written response within 21 days of the request, are 'directly enforceable as

103. The Care Recognition Act 2010 (Cth) defines 'carer' in s5 to mean 'an individual who provides personal care, support and assistance to another individual who needs it because the other individual' has a 'disability', 'medical condition', 'mental illness', or is 'frail and aged'. Chapman notes that a person is not a 'carer' 'merely because he or she is the spouse, de facto partner, parent, child or other relative, or lives with an individual who requires care': Anna Chapman, 'Is the right to request flexibility under the Fair Work Act enforceable?' (2013) Australian Journal of Labour Law 118, 124 (footnote 29).

104. Fair Work Act 2009 (Cth) s 65(1A) as amended.

105. s 65(2).

106. Rae Cooper and Marian Baird, 'Bringing the "right to request" flexible working arrangements to life: from policies to practices', Employee Relations, 2015 37:5, 568.

107. Title of Part 2-2, Division 4.

108. s 65(1).

109. s $65(3)$.

110. s 65(4).

111. s 65(5).

112. Chapman (n 103) 126. The other possible routes for challenging such a decision identified by Chapman do not seem relevant in the context of EU law, including dispute resolution and state level legislation. 
contraventions' of the Act. ${ }^{113}$ Chapman argues that, as certain procedural elements applicable to the request mechanism are directly enforceable, ${ }^{114}$ there is a 'partial enforcement regime'. ${ }^{115}$

Recently the procedural requirements linked to the right to request a change to working requirements have been tightened further. In 2018 the employer's obligations set out in the Fair Work Act were supplemented through the development of a standard clause to be included in industrial awards. Such awards are established by the Fair Work Commission and grant all employees in specific sectors certain employment rights. ${ }^{116}$ The awards are intended to establish a minimum safety net of employment terms and conditions, and are enforceable. As a result of this development, employers are now required to discuss the request to change working arrangements with the employee and genuinely to try to reach an agreement that will reasonably accommodate the employee's circumstances. Where an employer rejects a request, the employer is also subject to certain additional requirements regarding the written information that must be provided to the employee. The Legal Services Award, for example, requires employers to discuss the request with the employee and to try to reach agreement having regard to: the needs of the employee, the consequences for the employee if changes in working arrangements are not made, and any reasonable grounds for refusing the request. The Award also addresses the information the employer must include in the written response in the event that no agreement is reached with the employee. In such cases, the written response must include details of the reasons for the refusal, including the business ground(s) for the refusal and how the ground(s) apply. Where no agreement is reached, the written response must also indicate whether there are any changes in working arrangements which the employer can offer the employee to accommodate his or her circumstances, and, if the employer can offer such changes, set out what those changes are. If the employer and employee reach an agreement which is different from what was initially requested by the employee, then the employer's written response must set out the agreed changes in working arrangements. ${ }^{117}$ Such requirements are also found in awards governing other sectors.

The Australian Fair Work Act, as supplemented by requirements in industrial awards, places fairly stringent procedural obligations on employers, which are arguably intended to ensure that any request to change working arrangements receives serious attention, is dealt with in a transparent and timely manner, and is only refused based on legitimate and well-founded business requirements. The obligation, as under EU law, clearly does not extend to a right to receive flexible or changed working arrangements, but it involves a more demanding set of procedural requirements.

\section{More than a mere right to request?}

This article sought to identify the strengths, limitations and potential of the right to request flexible working arrangements, as well as its relationship to existing rights in EU law. Through a comparison with the provisions in the Parental Leave and Part-time Work Directives, it can be seen that

113. Ibid 126 .

114. Ibid 120 .

115. Ibid 123 .

116. See Fair Work Commission, 'Modern Awards' < https://www.fwc.gov.au/awards-and-agreements/awards/modernawards $>$ (accessed 18 March 2021).

117. The Legal Services Award, Part 1, 6: <https:/www.fwc.gov.au/documents/documents/modern_awards/award/ ma000116/default.htm> (accessed 18 March 2021). 
the Work-life Balance Directive expands significantly the personal scope of those who can exercise the right to request flexible working arrangements and, at the same time, it enlarges the understanding of what this might entail, most notably through the explicit reference to remote working arrangements. Yet these gains might be seen as pyrrhic victories if employers retain an unlimited prerogative to reject such requests for even the most flimsy or unpersuasive reasons. It remains uncertain whether, and to what extent, the CJEU might interpret the Directive as permitting scrutiny of the employer's reason for declining a request. The experience of the pandemic has provided unequivocal evidence that many jobs can be performed flexibly and remotely; the boundaries of our imagination of working life have been stretched and old certainties about what had to be done in the workplace have been shattered. It would, therefore, be a retrograde step if employers were able to reject requests for flexible working in the future even where the worker could point to concrete evidence that the job had already been performed effectively on such a basis.

A fuller appreciation of the potential of the Directive can be found through a combined analysis of protections found in other instruments, especially EU equality law. While the Work-life Balance Directive places an accent on procedural rights, Directives on equality ensure substantive rights in the form of protection from discrimination and the right to reasonable accommodation. In many situations, a worker who exercises the right to request flexible working arrangements will also fall within the scope of these Directives. Most commonly, such requests will arise from women and, as discussed in this article, a rejection of a request may constitute a prima facie case of indirect sex discrimination. Given the definition of carer in the Work-life Balance Directive, the recipient of the care will often be a person with a disability or a dependent older person. This implies that carers who exercise their right to request flexible working arrangements may also be able to benefit from the prohibition of discrimination by association on grounds of disability or age, which extends to both direct and indirect discrimination. It must also be recognised that disabled workers can also be parents and carers, so they may be able to rely on the right to reasonable accommodation in conjunction with the right to request flexible working arrangements.

An integrated vision of these different components of the legal framework, which are collectively underpinned by the EU Charter of Fundamental Rights, means that, in many situations, an employer is not completely at liberty to reject a request for flexible working arrangements without any significant reason for so doing. Those in organisations with responsibility for translating the law into workplace policies and procedures (often human resources) will need to ensure that decision-makers take into account the combined implications of various EU Directives when considering requests for flexible working. Of course, in the domestic context, organisations are likely to take their lead from the domestic transposition of the Work-life Balance Directive. The Directive sets minimum standards, so Member States may choose to go beyond its minimum framework for handling requests for flexible working arrangements. As illustrated through the two examples in this article, domestic law could flesh out the need for an employer to have sufficiently weighty reasons if the request is to be refused, or only partially granted. Taking this additional step may assist employers to comply simultaneously with wider obligations that flow from equality law, as well as the specific duties found in the Work-life Balance Directive. Moreover, Member States could choose to extend the personal scope of this right beyond the minimum requirement of the Work-life Balance Directive. In the wake of the pandemic, the desire for greater flexibility in working arrangements is unlikely to be confined to parents and carers. In this regard, the Directive offers a useful starting point for navigating the way in which work will be organised beyond the pandemic. 


\section{Author note}

Lisa Waddington, European Disability Forum Professor in European Disability Law, Faculty of Law, Maastricht University and Mark Bell, Regius Professor of Laws, Trinity College Dublin, the University of Dublin. The authors are grateful to the Department of International and European Law of Maastricht University for providing student assistant support to carry out an initial literature review.

\section{Declaration of conflicting interests}

The author(s) declared no potential conflicts of interest with respect to the research, authorship, and/or publication of this article.

\section{Funding}

The author(s) received no financial support for the research, authorship, and/or publication of this article.

\section{ORCID iDs}

Lisa Waddington (D) https://orcid.org/0000-0002-2017-4556

Mark Bell (D) https://orcid.org/0000-0003-0154-4651 